\title{
INTERACTION OF THE UKRAINE NATIONAL POLICE WITH OTHER SUBJECTS OF PUBLIC SECURITY IN THE CONDITIONS OF THE UNITED FORCES OPERATIONS
}

\begin{abstract}
Abroskin V. V.
INTRODUCTION

Issues of interaction of the National Police of Ukraine with state authorities, local self-government bodies and the public are an important component of effective work during holding joint events joint actions to ensure the protection of public order and public security, minimize administrative offenses, taking measures to enhancing the effectiveness of counteraction to crime in the area of the of the united forces operations.

For our country, the issue of cooperation between law enforcement and other public authorities became especially relevant with the beginning of armed aggression by the Russian Federation in the spring of 2014, which violated the sovereignty, independence and territorial integrity of our state. In connection with this, on 14.04.2014 the decision of the National Security and Defense Council of Ukraine «On urgent measures to overcome the terrorist threat and preservation of the territorial integrity of Ukraine» was put into effect. The date is considered the start of an antiterrorist operation $^{1,2}$.

On April 30, 2018, the President of Ukraine signed the Order «On the start of the united forces operations with implementation of national security and defense the suppression of armed aggression of the Russian Federation in the Donetsk and Luhansk Regions». According to the order, from 14:00 on April 30, 2018, started the united forces operations according to plan of the united forces operations. Subsequently, the President signed the order of the Commander-in-Chief «On approval of the provision about the Joint Operational Headquarters UFU» ${ }^{3}$.
\end{abstract}

\footnotetext{
${ }^{1}$ Про рішення Ради національної безпеки і оборони України від 13 квітня 2014 року «Про невідкладні заходи щодо подолання терористичної загрози і збереження територіальної цілісності України» : Указ Президента України від 14 квіт. 2014 р. № 405/204. URL: https://zakon.rada.gov.ua/laws/show/405/2014 (дата звернення: 20.11.2019).

${ }^{2}$ Про рішення Ради національної безпеки і оборони України від 30 квітня 2018 року «Про широкомасштабну антитерористичну операцію в Донецькій та Луганській областях» : Указ Президента України від 30 квіт. 2018 р. № 116/2018. URL: https://zakon5.rada.gov.ua/ laws/show/116/2018 (дата звернення: 21.11.2019).

${ }^{3}$ Ibid.
} 
However, despite the fact that the united forces operations has been underway for a long time, there are still many problems, one of which is the interaction of the National Police of Ukraine with state authorities, local authorities and the public in the area of the united forces operations. At present, such interaction is not going through the best of times due to insufficient funding of the Ministry of Internal Affairs of Ukraine, as well as due to constant personnel changes of the heads of the National Police of Ukraine. All this leaves a negative impact on the establishment of a new European-level law enforcement system.

According to Art. 2 of the Law of Ukraine «On National Police» the issue of ensuring public security is one of the key spheres of implementation of the tasks of the police, including its interaction ${ }^{4}$, while the legal principles of cooperation in the conditions of the united forces operations are defined in the Law of Ukraine «On the fight against terrorism» ${ }^{5}$. However, there was not enough one law to coordinate all subjects in the fight against terrorism, as well as to solve serious problems.

The review of legal literature gives grounds to claim that the theoretical and practical issues of the organization of interaction both in general and certain aspects of it have repeatedly been the subject of scientific researches by O.M. Bandurka, O.I. Bezpalova, Y.P. Bytyak, I.P. Golosnichenko, O.M. Klyueva, V.K. Kolpakova, A.T. Komzyuka, V.M. Plishkina, V.V. Sokurenko, O.Y. Sinyavskaya, V.O. Shamrai, Y.V. Kharchenko and others. However, works of these researchers did not take into account the peculiarities of the interaction of the National Police with other subjects of public security entities in the context of the united forces operations, which confirms the relevance of the research of these issues.

Thus, one of the most pressing problems of interaction of the National Police of Ukraine with the state authorities, local self-government bodies and the public in the area of the united forces operations. Thus, this remains the absence of a general legal act that would regulate the interaction of public administration entities and the sequence of concerted actions during the execution of both joint and separate tasks in the area of the united forces operations.

\footnotetext{
${ }^{4}$ Про Національну поліцію : Закон України від 02 липн. 2015 р. № 580 - VIII. URL: https://zakon.rada.gov.ua/laws/show/580-19 (дата звернення: 21.11.2019).

${ }^{5}$ Про боротьбу з тероризмом : Закон України від 20 бер. 2003 р. № 638-IV. URL: https://zakon.rada.gov.ua/laws/show/638-15/ed20090611 (дата звернення: 23.11.2019).
} 


\section{The interaction of the National Police with state authoroties and local self-government bodies in the area of the united forces operations}

Let's stop at the characterization of the etymological content of the concept of «interaction». This term is widely used in theory and in practice in various fields of knowledge, each of which gives it its definition. Thus, in the Great Explanatory Dictionary of Modern Ukrainian Language, the term «interaction» is interpreted as «cooperation, cooperation. Relationship between objects in action, as well as concerted action between someone or something» ${ }^{6}$.

In the broad sense, «interaction» is a joint action, that is, the interaction between the objects in action and the concerted action between them ${ }^{7}$; interaction serves as a form of communication of elements of the system by which they, by complementing each other, create the conditions for the successful functioning of the system as a whole; the state of interconnections between the elements of the system by which they interact with each other and the relevant field of activity ${ }^{8}$.

Based on the etymology of the word «interaction», we should note its similarity to the term "coordination», which in the reference literature is understood as the coordination, alignment, correlation between actions, objects, people, movements, etc. ${ }^{9}$. This was the root cause of lively discussions among scientists about the relationship between the concepts of «interaction» and «coordination».

Without going into the controversy over the relation between the concepts of «interaction» and «coordination», we think that the understanding of coordination proposed by V.M. Plishkin, according to which it is a management activity, aimed at harmonizing the functioning of elements of the system of law enforcement agencies in a mode that ensures the most effective achievement of the goals set before the system of goals, that is, coordination consists in the organization, first of all, by legal means, of interaction between elements of the system ${ }^{10}$.

\footnotetext{
${ }^{6}$ Великий тлумачний словник сучасної української мови / уклад. і голов. ред. В. Т. Бусел. Київ ; Ірпінь : Перун, 2009. 1736 с.

${ }^{7}$ Новий тлумачний словник української мови : у 4 т. Т. 1 / уклад.: В. Яременко, О. Сліпушко. Київ : Аконіт, 1998. 910 с.

${ }^{8}$ Плішкін В. М. Теорія управління органамй внутрішніх справ : підручник / за ред. Ю. Ф. Кравченка. Київ : Нац. акад. внутр. справ України, 1999. 702 с.

${ }^{9}$ Великий тлумачний словник сучасної української мови / уклад. і голов. ред. В. Т. Бусел. Київ ; Ірпінь : Перун, 2009. 1736 с.

${ }^{10}$ Плішкін В. М. Теорія управління органами внутрішніх справ : підручник / за ред. Ю. Ф. Кравченка. Київ : Нац. акад. внутр. справ України, 1999. 702 с.
} 
Thus, the main signs that characterize the theoretical concept of «interaction» of certain entities, include the following: 1) interaction requires the presence of at least two entities; 2) the subjects of the interaction are united by a single goal of accomplishing common tasks (unity and orientation of the functioning of the interacting entities); 3 ) interaction consists in the coordination of actions (implementation of measures) of the subjects by purpose, time, venue and program; 4) during the interaction, each of the interacting entities acts within the defined powers; 5) the interaction process is the object of normative legal regulation, the specifics of which are determined by the type of subjects of interaction; 6) in relation to coordination, the interaction between the entities is the object of management coordination activities.

The interaction of the National Police with state authorities and local self-government bodies are in accordance with the general provisions of the Law of Ukraine «On the National Police». Thus, Article 5 of the said Law stipulates that «in the course of its activity, the police shall interact with law enforcement and other public authorities, as well as local self-government bodies in accordance with the law and other normative legal acts» ${ }^{11}$.

The content of the interaction of the National Police is more broadly disclosed in p. 8 of the Regulation on the National Police, approved by the Cabinet of Ministers of Ukraine from 28.10.2015 № 877, according to which «the National Police, in the performance of its tasks, interacts with other state bodies, subsidiary bodies and services formed by the President of Ukraine, temporary advisory, advisory and other auxiliary bodies established by the Cabinet of Ministers of Ukraine, local self-government bodies, citizens' associations, public associations ILOs, trade unions and employers' organizations, relevant bodies of foreign countries and international organizations, as well as enterprises, institutions and organizations» 12 .

According to Art. 4 of the Law of Ukraine «On the Fight Against Terrorism», the entities that directly fighting against terrorism within their competence include: Ministry of Internal Affairs of Ukraine; Ministry of Defence Ukraine; central executive bodies that ensure the formation and implementation of state policy in the field of civil protection; the central

\footnotetext{
${ }^{11}$ Про Національну поліцію : Закон України від 02 липн. 2015 р. № 580 - VIII. URL: https://zakon.rada.gov.ua/laws/show/580-19 (дата звернення: 21.11.2019).

${ }^{12}$ Про затвердження Положення про Національну поліцію : Постанова Кабінету Міністрів України від 28 жовт. 2015 р. № 877. URL: http://zakon.rada.gov.ua/laws/show/ 877-2015 - п (дата звернення: 19.11.2018).
} 
executive body implementing state policy in the field of state border protection; the central body of the executive power, which implements the state policy in the sphere of execution of criminal penalties; Department of State Protection of Ukraine; central executive body implementing state tax policy, state policy in the field of state customs ${ }^{13}$.

Among the subjects directly engaged in the fight against terrorism, the National Guard of Ukraine plays a leading role in ensuring public security, which directly follows from the list of the main functions of the latter, including: 1) protection of the constitutional order of Ukraine, the integrity of its territory from attempts to change them by force; 2) protection of public order, ensuring protection of life, health, rights, freedoms and legitimate interests of citizens; 3) participation in the provision of public safety and public order during meetings, rallies, marches, demonstrations and other mass events that pose a danger to the life and health of citizens (Art. 2 of the Law of Ukraine «On the National Guard») ${ }^{14}$.

This stipulates the need to cover issues of interaction between the National Guard of Ukraine and the National Police regarding public security in the area of the united forces operations.

At the departmental level, by the order of the Ministry of Internal Affairs of Ukraine from 10.08.2016 № 773 defined the mechanism of organizing the interaction of the National Guard of Ukraine and the National Police of Ukraine in the sphere of ensuring (protection) of public (public) security and order ${ }^{15}$. In particular, according to the Order of organization of interaction between the National Guard of Ukraine and the National Police of Ukraine while ensuring (protection) of public (public) security and the order approved by the order of the Ministry of Internal Affairs of Ukraine №773, the interaction between these entities shall be carried out within the limits specified by the legislation, by: 1) joint patrolling of streets, squares, parks, stations, airports, seaports and river ports, other public places; 2) ensuring (protection) of public security and order during meetings, rallies, street campaigns, demonstrations, other mass and sports events, as well as during events in public places with the participation of people for whom the state is carried out protection;

\footnotetext{
${ }^{13}$ Про боротьбу 3 тероризмом : Закон України від 20 бер. 2003 р. № 638-IV. URL: https://zakon.rada.gov.ua/laws/show/638-15/ed20090611 (дата звернення: 23.11.2019).

14 Про Національну гвардію України : Закон України від 13 бер. 2014 р. № 876-VII. URL: https://zakon.rada.gov.ua/laws/show/876-18 (дата звернення: 12.10.2019).

15 Про затвердження Порядку організації взаємодії Національної гвардії України та Національної поліції України під час забезпечення (охорони) публічної (громадської) безпеки і порядку : Наказ МВС України від 10 серп. 2016 р. № 773. URL: http://zakon1.rada.gov.ua/ laws/show/z1223-16 (дата звернення: 28.11.2019).
} 
3) carrying out joint actions in order to stabilize the operational situation in case of its aggravation within the territory of one or more administrativeterritorial units.

It is important to note that this provision is effective only in peacetime, except during a state of emergency (p. 2, p. 1 of the order of organization of interaction between the National Guard of Ukraine and the National Police of Ukraine while ensuring (protection) of public (public) security and order). At the same time, despite the obvious necessity, the issues of interaction between the National Police and the National Guard of Ukraine on ensuring public security in the context of the anti-terrorist operation did not find their proper coverage within the framework of this legal act. Therefore, it is important to make appropriate additions to the Order of organization of interaction between the National Guard of Ukraine and the National Police of Ukraine while ensuring (protection) of public (public) security and the order, which should provide features of interaction between the National Police and the National Guard of Ukraine on ensuring public security not only in peacetime, but also in the context of the united forces operations.

The Law of Ukraine «On the Fight Against Terrorism» provides possibility of involvement in participation in the united forces operations. The Law of Ukraine «On Combating Terrorism» provides for the possibility of involving any central and local executive authorities, local self-government bodies, enterprises, institutions, organizations regardless of their subordination and ownership, their officials, and citizens with their consent (p. 5, 6, Art. 4). Interaction of state bodies, local self-government bodies, associations of citizens, organizations, their officials as reports on information they have become aware of, about terrorist activity or any other circumstances, information about which can contribute to the prevention, detection and termination of terrorist activity, as well as minimizing its consequences, in particular to the bodies of the National Police, is a mandatory requirement under Art. 9 of the Law of Ukraine «On the Fight Against Terrorism».

The relevant provisions of the Title Law correspond to the content of the normative acts that regulate the activity of the respective bodies. For example, Art. 38 of the Law of Ukraine «On Local Self-Government in Ukraine» to the authority to ensuring the law, order, protection of rights, freedoms and legitimate interests of citizens related "promoting activities of the bodies of the National Police, as well as the court, the prosecutor's office, justice, the security service, the National Anti-Corruption Bureau of 
Ukraine, the Advocacy and the State Criminal Enforcement Service of Ukraine» (p. 2 p. 1).

In turn, solution of the issue of the essence of the interaction of the National Police with other public security entities in the context of the united forces operations needs to cover not only the legal basis, but also the practice of implementing specific measures by the relevant entities.

Thus, thanks to the effective cooperation of the Ministry of Internal Affairs of Ukraine, the National Police, regional and city councils, representatives of business structures and the public, a Unified Analytical Service Center (UASC) was established in Donetsk region ${ }^{16}$.

Analytical Center created on the example of the Abu Dhabi security system and became the first unit in Ukraine based on smart technologies. Similar systems are in Singapore, London and now in Mariupol. Intelligent software designed specifically for the needs of the region's police forces, where fighting takes place and allows for the quickest response to events, prevention of crime and crime detection in the first hours after committing.

Components that work in a single UASC system: call center 102, intelligent video surveillance system, mobile application «Police 102», smart public transport stop in Mariupol. All of this is a part of a joint police and community project - «Safe Donetsk». The system works even where there is almost no connection, in remote locations and on the battle line. Thanks to modern equipment, IP-telephony, residents have the opportunity to notify law enforcement officers of the offense, which will be automatically fixed and the police will come to the aid immediately specially equipped and ready for any situations ${ }^{17}$.

In cooperation with local communities and the United Nations Development Program, intelligent video surveillance cameras have been installed in Mariupol, Pokrovsk, Velyka Novosilka, Slavyansk and frontline Novgorod, that work in crowds, junctions, in and out of cities. Camcorders are the only ones in the country able to identify the brand, model and color of a car, responding to loud sounds and flashes.

The Unified Analytical Service Center program has over 700 functions; more than 100 smart camcorders work; within 15 seconds the camera recognizes the danger and sends an alarm to the center; call handling and referral for police assistance takes 3-5 minutes; with the introduction of the UASC, the number of calls to the police has doubled.

\footnotetext{
${ }^{16}$ В Маріуполі запустили Єдиний аналітичний сервісний центр UASC. Everest.ua : вебсайт. URL: https://www.everest.ua/v-mariupoli-zapustyly-yedynyy-analitychnyy-servisnyytsentr-uasc (дата звернення 15.11.1019).

${ }^{17}$ Ibid.
} 
Having reviewed with the experience of the Donetsk police in the field of «reasonable» security, including for the release of the abducted person, the leadership of the National Police decided to use the Donetsk Police Unified Analytical Service Center as an example in implementing a security program throughout Ukraine.

In addition, with a view to timely identification of the facts of sending and receiving weapons and explosives, which are sent with the aim of destabilizing the socio-political situation and further deepening the conflict in Donetsk and Luhansk regions, special attention is paid to establishing a constant dialogue and interaction of the National Police with the management of regional offices of Ukrposhta, express delivery of Nova Poshta and other organizations that providing luggage services.

An important area of interaction between the National Police and other law enforcement agencies and volunteers is the search for missing, abducted citizens and captured people. For this purpose, systematically exchanges information with the Joint Center for Coordination of Search, release of unlawfully imprisoned people, hostages, and detection of missing people in the area of anti-terrorist operation that operated by the SSU. Interaction is also taking place with the Armed Forces Law Enforcement Service, the State Border Guard Service of Ukraine, territorial units of the forensic expertise of the Ministry of Health of Ukraine, the National Committee of the Red Cross of Ukraine, and volunteer organizations that keep records of the missing, captured and captured people. Thanks to the joint measures taken, including as a result of the Minsk Agreements, the number of unidentified missing people was reduced.

The research of the administrative and legal content of the interaction of the National Police with other state authorities and local self-government bodies in the area of the operation of the Joint Forces led to the conclusion that the interaction can have two directions: the first is the internal one, which is to coordinate activities with entities directly engaged in combating terrorism within a single state prevention system, responding and ending of terrorist acts and minimizing their consequences; the second is external, coordination of activities with other equal, independent bodies of state power, bodies of local self-government, enterprises, institutions and organizations regardless of subordination and form of ownership, as well as the public.

In our turn, we have found out that the existing administrative normative acts that regulating the interaction of the National Police with other state authorities (first of all, the entities directly engaged in the fight against terrorism) in the field of public security, do not meet the current 
challenges of the fight against terrorism. Instead, the organizational and legal aspects of the interaction of the National Police with the entities that engaged in direct counter-terrorism that were developed in the context of the anti-terrorist operation and the united forces operations in the eastern regions of Ukraine during 2014-2019, should become a key source for improvement of the legal framework in the sphere of interaction of the described bodies.

\section{Interaction of the National Police of Ukraine with the public in the area of the united forces operations}

Issues of interaction between the National Police and the public in the performance of its public security and law enforcement responsibilities in the area of the united forces operation are defined by the current legislation of Ukraine as key and that, which determine the success of the police bodies and units.

In Art. 11 of the Law of Ukraine «On National Police», «interaction of police with the population on the basis of partnership» has been called one of the principles of the National Police. The content of this principle is as follows: a) police activities are carried out in close cooperation and interaction with the public, territorial communities and public associations on the basis of partnership and aimed at meeting their needs; b) in order to determine the causes and / or conditions of committing offenses of planning of service activities of police bodies and units is carried out taking into account the specificity of the region and the problems of territorial communities; c) the level of public trust in the police is the main criterion for evaluating the effectiveness of the activities of police bodies and units ${ }^{18}$.

The Law of Ukraine «On the National Police» also stipulates that the police interact with the public through the preparation and implementation of joint projects, programs and activities to meet the needs of the population and improve the effectiveness of the police in carrying out their tasks. In particular, the police support legal education programs, promote legal knowledge in educational institutions, the media and in publishing activities (Art. 89).

Cooperation between the police and the public is aimed at identifying and eliminating problems related to policing and promoting the use of modern methods to increase the efficiency and effectiveness of such

18 Про Національну поліцію : Закон України від 02 липн. 2015 р. № 580 - VIII. URL: https://zakon.rada.gov.ua/laws/show/580-19 (дата звернення: 21.11.2019). 
activities. In particular, control over police activity can be carried out in the form of involving members of the public in joint consideration of complaints about the actions or omissions of police officers and verification of information on the proper performance of their duties in accordance with the laws and other legal acts of Ukraine (Art. 89, 90 of the Law of Ukraine «On National Police») ${ }^{19}$.

In order to determine the causes and conditions of committing offenses, planning of service activities of police bodies and units is tailored to the specificity of the region and problems of local communities, and the level of public trust in the police is the main criterion for evaluating the effectiveness of police activity.

Except to the above, the heads of territorial bodies and police units should hold open meetings with representatives of local governments at the levels of regions, districts, cities and villages at least once every two months in order to establish cooperation between the police and local authorities and the population. Such meetings discuss activities of the police, identify current problems and select the most effective ways to solve them.

In order to increase the authority and confidence of the population in the police, the bodies and units of the National Police of Ukraine should systematically inform the public about the state of law and order, that used to prevent offenses.

An important area of interaction between the police and the population the legislation defines the preparation and implementation of joint orders, programs and measures to meet the needs of the population and to improve the effectiveness of police implementation of their assigned tasks. In addition, the police have an obligation to support legal education programs, to promote legal knowledge in educational institutions and the media.

These provisions of the current legislation on the necessity of interaction between the national police of Ukraine and the public can be summarized as follows:

1) the police must carry out their duties taking into account the needs of the local community and individual groups of its population;

2) the management of territorial units of the police should hold meetings with representatives of local self-government bodies, at which the activities of the police should be discussed, the current problems of public safety of citizens and ways of their solution should be solved;

19 Про Національну поліцію : Закон України від 02 липн. 2015 р. № 580 - VIII. URL: https://zakon.rada.gov.ua/laws/show/580-19 (дата звернення: 21.11.2019). 
3) units of the National Police should inform the public about the state of law and order in the subordinate territory;

4) the police and members of the public can develop joint projects, programs and activities to meet the needs of the population, as well as improve the effectiveness of the police in carrying out their tasks;

5) the police should be involved in legal education of the population.

The analysis of information sources of the Main Directorates of the National Police in Lugansk and Donetsk regions shows that work is being done to establish interaction with the population in the following areas:

1) Work of public organizations of legal direction. A striking example of interaction between the National Police and the public is the creation of a public organization "Youth League of Future Police», involving young people aged 14 to 35 who has an interest and desire to contribute to the activities of the National Police, seeks to study military special and physical training, historical traditions of Ukraine ${ }^{20}$. The main purpose of the Future Police League is to carry out activities aimed at realizing creative abilities, improving the moral, patriotic education of young people, raising their awareness, aimed at preventing the commission of offenses, neglect and homelessness, providing them with opportunities for self-realization, self-realization lifestyle.

The positive achievements of the Future Police League are the development of skills needed to protect rights and freedoms; education of youth in the spirit of patriotism and observance of generally accepted norms and rules of behavior; involvement of young people in practical human rights work; assistance to the territorial bodies of the Main Directorate of the National Police in Donetsk region in the work on prevention of neglect and offenses among teenagers and youth.

In addition, the United Nations Development Program proposed a joint project with the League of Future Police «League of Action», which concerned mediation in schools. Public organisations of Mariupol provided a methodology for training mediators. Thus, together with the police of Donetsk region, the first thirty mediators were trained. In addition, ten UNICEF-supported schools in the city have school-based liaison services. The latter consist of students who will independently reconcile peer conflicts through mediation ${ }^{21}$.

\footnotetext{
${ }^{20}$ Програма громадської організації «Молодіжна ліга майбутніх поліцейських». Liga-police. ucoz.net : веб-сайт. URL: https://liga police.ucoz.net/index/programa_gromadskoji_organizaciji_ 39_39_molodizhna_liga_majbutnikh_policejskikh_39_39/0-4 (дата звернення: 23.11.2019).

${ }^{21}$ Ibid.
} 
2) Another example of police-public interaction is the Swallow project, initiated by the public organization «Trust Fund» with the assistance of the United Nations Development Program. As part of this project, 18 volunteers from the Mariupol Police Department and General have been trained in sign language and fingerprinting.

On August 3, 2018, for the first time in Ukraine, the Head of the Police of Donetsk Region, Mykola Semenyshyn, handed over certificates to operative commissioners, investigators, district police officers and inspectors of juvenile prevention with knowledge of sign language and dactyl. Police officers successfully trained and in a new format provide services to hearing impaired citizens ${ }^{22}$.

3) Particular attention should be paid to joint projects of the Donetsk police and the public, such as: the Safe House Innovation Project; creation of a safe workplace for police officers serving at posts in Donetsk region; the School Police Officer project; pilot project «Polina»; Neighborhood Watch project ${ }^{23}$.

On November 3, 2018, in Donetsk region, in the frontline region, police implemented the project «School Police Officer», with the aim of safe stay of children in the educational institutions of Mariupol, Kramatorsk and Slavyansk. The aim of the project is to solve the problem of juvenile and child crime in Mariupol educational institutions by combining the efforts of the police who provide crime prevention and the schools responsible for teaching children ${ }^{24}$.

The Safe House project is part of a unified strategy for the development of the Ministry of Internal Affairs and unites the efforts of law enforcement, local authorities, self-organizing committees and associations of co-owners of apartment buildings for the safety of citizens and involves a tripartite cooperation: «Police - Community - Government». This program helps residents of multi-storey buildings to determine their own level of safety ${ }^{25}$.

\footnotetext{
${ }^{22}$ Проект «Ластівка»: 18 поліцейських Донеччини отримали сертифікати сурдоперекладачів. Mariupol-police.dn.uа : веб-сайт. URL: http://mariupol-police.dn.ua/news/view/3571 (дата звернення: 23.11.2019).

${ }^{23}$ Вітвіцький С. С. Консолідація діяльності органів Національної поліції та потенціалу громадськості як стратегічний напрямок забезпечення публічного порядку в умовах операції Об'єднаних сил. Забезпечення правопорядку на території проведення операції Об'єднаних сил : матеріали Всеукр. наук.-практ. семінару, 12 жовт. 2018 р. Маріуполь : МДУ, 2018. С. 179-188.

${ }^{24}$ На Донеччині поліцейські впровадили проект «Шкільний офіцер поліції». Поліція Донеччини: веб-сайт. URL: http://police.dn.ua/news/view/na-donechchini-politsejski-vprovadiliproekt-shkilnij-ofitser-politsii (дата звернення: 23.11.2019).

${ }^{25}$ В центрі Краматорська 3'явився «Безпечний будинок». Полічія Донеччини : веб-сайт. URL: http://police.dn.ua/news/view/v-tsentri-kramatorska-zyavivsya-bezpechnij-budinok (дата звернення 15.11.1019).
} 
On February 6, 2018, the mobile group «Polina» started operating in the Left Bank District of Mariupol in order to respond to the facts of domestic violence. In the future, the work of the group began to operate throughout the Donetsk region. Police respond to calls for combating domestic violence, draw up reports of administrative offenses for committing domestic violence, and open criminal proceedings when establishing the facts of personal injury. In addition, police inspect persons who are on and off the record for committing domestic violence: communicating with victims and neighbors about re-committing domestic violence. For systematic preventive work with the aggressors, the police plan to create a «map of the offender» with information on social status, place of work, number of children, etc.

Now, for police officers are conducting trainings on countering domestic violence, which have been implemented with the assistance of public organizations «Council of Women of Donetsk Region» and «Mariupol Youth Union».

Over the first half of 2019, more than 23,000 people have contacted «La Strada - Ukraine» national hotlines for domestic violence ${ }^{26}$.

Since 2017, the Neighborhood Watch Project has been launched thanks to the initiative of residents in cooperation with patrol officers, local authorities and international partners. The main task of the neighborhood watch approach is to develop a bona fide neighborhood and a shared responsibility for the safety of one's home and yard. The project provides for: prevention of crime by increasing the vigilance of neighbors and their awareness of the area; improving the safety of the community; a sense of security of your own space; improving communication between the community, the police and other public authorities and local selfgovernment through active communication; the ability to respond properly to security threats by obtaining credible information from police representatives and having a clear algorithm for responding to such threats; improvement of the yard $^{27}$.

4) In the area of the united forces operations, police cooperation with public formations on public order and state border deserves special attention. In accordance with the provisions of the Constitution of Ukraine,

26 Поліція поширює проєкт протидії домашньому насильству «Поліна» на всю Україну - Клименко. Radiosvoboda.org : веб-сайт. URL: https:/www.radiosvoboda.org/a/ news-policija-poshyriye-proekt-protydii-domashniomu-nasylstvu-na-vsiu-ukrainu-

klymenko/30204166.html (дата звернення: 23.11.2019).

27 Сусідська варта: безпека-добробут-порядок. На Галичині і в Донбасі. Prostir.ua : веб-сайт. URL: https://www.prostir.ua/?news=susidska-varta-bezpeka-dobrobut-poryadok-nahalychyni-i-v-donbasi (дата звернення: 23.11.2019). 
citizens of Ukraine have the right to create in the statutory law of Ukraine «On citizens' participation in the protection of public order and the state border» - public associations, to participate in the protection of public order and the state border, to assist local authorities, law enforcement agencies, the State Border Service of Ukraine and executive authorities, as well as officials in the prevention and termination of administrative offenses and crimes, protection of life and crime, citizens, interests of society and the state from unlawful encroachments, as well as in the rescue of people and property during natural disasters and other extraordinary circumstances ${ }^{28}$.

The content of the interaction of the National Police with public formations in the protection of public order in the field of public security is easy to evaluate based on the content of their main tasks (Article 9 of the Law of Ukraine «On Participation of Citizens in the Protection of Public Order and State Border»), namely: assisting the National Police in the maintenance of public order and public safety, the prevention of administrative misconduct and crimes; informing the bodies of the National Police about the crimes committed or in preparation, the places of concentration of criminal groups; assistance to the bodies of the National Police in the detection and disclosure of crimes, the search of people who have committed them, the protection of the interests of the state, enterprises, institutions, organizations, citizens from criminal encroachments; participation in road safety and combating child neglect and juvenile delinquency.

In Donetsk Oblast, in accordance with the requirements of the Law «On Citizens' Participation in the Protection of Public Order and the State Border», 33 public formations were created and registered (12 of them in 2018). The total number of members of public formations is 390 (of which 189 were recruited in 2018). During 2017, the Donetsk police together with public formations carried out 857 public order actions, 316 joint preventive raids. Within the framework of the support program, the regional state administration has allocated funds for the promotion of public formations. During the events with the participation of members of public formations, 1137 people were detained for committing offenses, 52 of them - criminal and 1085 - administrative offenses ${ }^{29}$.

\footnotetext{
${ }^{28}$ Про участь громадян в охороні громадського порядку і державного кордону : Закон України від 22 черв. 2000 р. № 1835-III. URL: http://zakon.rada.gov.ua/laws/show/1835-14 (дата звернення: 13.02.2018).

${ }^{29}$ Війна зобов'язала поліцейських на Донбасі стати краще. Communiti policing : вебсайт. URL: http://cop.org.ua/ua/ukrainskyi-dosvid/donetska-oblast/general-mikola-semenishinvijna-zobov-yazala-politsejskikh-na-donbasi-stavati-krashchimi_(дата звернення 15.11.1019).
} 
Members of the public formations, together with the police, that patrol streets and participate in preventive raids, in particular to counteract the spontaneous trade and sale of surrogate alcohol, traffic safety.

5) The implementation of the "Thin Blue Line» social project is an example of the interaction and support that residents express to police officers, and the blue ribbon in private and networked institutions is a sign that they trust the police. In Mariupol, several businesses have already joined this project and each has a corresponding symbol of engagement - blue ribbon. This project was also joined in Konstantinovka and Slavyansk ${ }^{30}$.

In the light of these examples, the units of the National Police of Ukraine, which operate in the area of the united forces operations, use a very large number of forms of interaction with civil society institutions. However, these activities can be significantly optimized and improved, taking into account the international experience of such policing.

Summarizing the issues of interaction of the National Police with the public in the area of the united forces operations, it can be concluded that the potential of the public and the police is the basis for improving the effectiveness of all subjects in achieving the goals of maintaining public safety in society, and coordination will provide police relations and public formation of a sustainable, purposeful nature, will ensure the optimal distribution of law enforcement functions, unity of strategic and tact their actions.

In turn, the main forms of interaction between the National Police and the public, including in the area of the united forces operations, can be attributed to: involvement of the public in human rights work; citizen participation in maintaining public safety and order; informing the police about crimes and people who involved in committing them (preparation); organizational assistance of an informative nature regarding the search of missing persons; participation of the public in the training of police officers in the formation of narrow-sector knowledge to meet the needs of the population; providing logistical support to improve police activities; implementation of programs of legal and patriotic education of the population; capacity building for National Police bodies through the implementation of joint projects for youth seeking legal, military-special and physical training, etc.

Based on the above characteristics, the interaction of the National Police with other public security entities during the united forces

30 До ініціативи «Тонка синя лінія» приєднався магазин побутової техніки. Mariupolpolice.dn.иа : веб-сайт. URL: http://mariupol-police.dn.ua/news/view/4939 (дата звернення: 23.11.2019). 
operations should be understood as based on legislative and regulatory acts agreed upon by purpose, time, place of activity between the entities that directly carry out combat terrorism arising from the organizational activities of the specially created coordination bodies, and other equally independent state bodies, local self-government bodies and the public for the purpose of their concerted functioning in protecting the rights, freedoms and ensuring the safety of citizens, and the cessation of acts of terrorism and other offenses by the most expedient combination of the forms and methods peculiar to those subjects.

Consequently, the fulfillment of public security tasks by the police, in particular in the context of the united forces operations, depends to a large extent on its interaction with counter-terrorism bodies, other public authorities, local self-government bodies and civil society institutions. In the course of such interaction, there is a constant exchange of information on problematic issues and elimination of factors that destabilize the situation in the region, coordinate actions with members of the public, media coordinators, local people who involved in maintaining public order, public and private organizations, that provide security services, delivery, etc. to effectively control the operational environment and implement joint actions in the event of a real terrorist threat.

\section{CONCLUSIONS}

The interaction of the National Police with other public security entities during the united forces operations is necessary to understand the legislation and regulations based on the goals, time, place of activity between the entities, that directly carry out combat terrorism arising from the organizational activities of the specially created coordination bodies, and other equally independent state bodies, local self-government bodies and the public for the purpose of their concerted functioning in protecting the rights, freedoms and ensuring the safety of citizens, and the cessation of acts of terrorism and other offenses by the most expedient combination of the forms and methods peculiar to those subjects.

The interaction of the National Police with the authorities, local selfgovernment and the public in the area of the united forces operations depends directly on: from developing plans of interaction at the state and local levels; mutual information on socio-economic, military-political, strategic and operational situation; defining the scope and sequence of joint actions in the performance of joint and individual service tasks; coordination of the procedure of joint actions for making urgent decisions of subordination and interaction of units in the process of performing joint 
tasks, solving issues of logistics; co-ordination of joint actions (joint determination of placements, staffing and order of joint activities; assessing the nature of the threat, status and capabilities of available forces and means; determining the leader of joint events in agreement with the leaders of the interacting parties; determining the need to involve other additional forces and means.

Built at the Main Police Department in the Donetsk region Built at SUNP in the Donetsk region, the unique Unified Analytical Service Center (UASC) in Mariupol allowed to bring the level of citizens' safety to a new level by focusing on the introduction of the latest technologies, building on the best international experience of countries such as the United Kingdom, United Arab Emirates Emirates and Italy. Thanks to the UASC, in the context of the united forces operations, the police work in the following areas: improving the security of citizens; modernization and development of technologies of the automated security management infrastructure of the designated area; use of advanced technologies for effective city management; active involvement of the police, local authorities, the business environment and the public.

Particular attention should be paid to such joint projects by the Donetsk police and the public as: the Safe House Innovation Project; creation of a safe workplace for police officers serving at posts in Donetsk region; «the School Police Officer» project; pilot project «Polina»; «the Thin Blue Line» project; Neighborhood Watch project and cooperation with the public organization «Future League of Police Officers».

\section{SUMMARY}

The article is devoted to the study of the main provisions of the interaction of the National Police with state authorities, local selfgovernment and the public in the area of the united forces operations. Theoretical approaches to the definition and correlation of the concepts of «interaction» and «coordination» are investigated. The concept of interaction of the National Police with other subjects in the field of public security and order during the united forces operations is formulated. The main directions of cooperation of the National Police bodies with other state authorities and local self-government bodies in the area of the united forces operations are determined. The basic tasks and functions of these entities in relation to the interaction in the area of the united forces operations are disclosed. The activity of unique Unified Analytical Service Center (UASC), which was created on the basis of the Main Police Department in Donetsk region, is analyzed. The work of public 
organizations with which the National Police of Ukraine interacts is characterized by: "Youth League of Future Police Officers»; «the Swallow» project; «Safe House» project; «the Polina» Project; «the School Police Officer» project; «the Neighborhood Watch» project; social project «Thin Blue Line». The content of the interaction of the National Police with public formations in the field of public order concerning the provision of public security in the area of the united forces operations is disclosed.

\section{REFERENCES}

1. Про боротьбу з тероризмом : Закон України від 20 бер. 2003 р. № 638-IV. URL: https://zakon.rada.gov.ua/laws/show/638-15/ed20090611 (дата звернення: 23.11.2019).

2. Про місцеве самоврядування в Україні : Закон України від 21 трав. 1997 р. № 280/97-BP. URL: https://zakon.rada.gov.ua/laws/ show/280/97-вр (дата звернення: 09.11.2019).

3. Про Національну гвардію України : Закон України від 13 бер. 2014 p. № 876-VII. URL: https://zakon.rada.gov.ua/laws/show/876-18 (дата звернення: 12.10.2019).

4. Про Національну поліцію : Закон України від 02 липн. 2015 p. № 580 - VIII. URL: https://zakon.rada.gov.ua/laws/show/580-19 (дата звернення: 21.11.2019).

5. Про участь громадян в охороні громадського порядку і державного кордону : Закон України від 22 черв. 2000 р. № 1835-III. URL: http://zakon.rada.gov.ua/laws/show/1835-14 (дата звернення: 13.02.2018).

6. Про рішення Ради національної безпеки і оборони України від 13 квітня 2014 року «Про невідкладні заходи щодо подолання терористичної загрози і збереження територіальної цілісності України» : Указ Президента України від 14 квіт. 2014 р. № 405/204. URL: https://zakon.rada.gov.ua/laws/show/405/2014 (дата звернення: 20.11.2019).

7. Про рішення Ради національної безпеки і оборони України від 30 квітня 2018 року «Про широкомасштабну антитерористичну операцію в Донецькій та Луганській областях» : Указ Президента України від 30 квіт. 2018 р. № 116/2018. URL: https://zakon5.rada.gov.ua/ laws/show/116/2018 (дата звернення: 21.11.2019).

8. Про затвердження Положення про Національну поліцію : Постанова Кабінету Міністрів України від 28 жовт. 2015 р. № 877. URL: http://zakon.rada.gov.ua/laws/show/877-2015 - п (дата звернення: 19.11.2018). 
9. Про затвердження Порядку організації взаємодії Національної гвардії України та Національної поліції України під час забезпечення (охорони) публічної (громадської) безпеки і порядку : Наказ МВС України від 10 серп. 2016 р. № 773. URL: http://zakon1.rada.gov.ua/ laws/show/z1223-16 (дата звернення: 28.11.2019).

10.В центрі Краматорська з'явився «Безпечний будинок». Полічуія Донеччини : веб-сайт. URL: http://police.dn.ua/news/view/v-tsentrikramatorska-zyavivsya-bezpechnij-budinok (дата звернення 15.11.1019).

11. Великий тлумачний словник сучасної української мови / уклад. і голов. ред. В. Т. Бусел. Київ ; Ірпінь : Перун, 2009. 1736 с.

12. Вітвіцький С. С. Консолідація діяльності органів Національної поліції та потенціалу громадськості як стратегічний напрямок забезпечення публічного порядку в умовах операції Об'єднаних сил. Забезпечення правопорядку на території проведення операції Об'єднаних сил : матеріали Всеукр. наук.-практ. семінару, 12 жовт. 2018 р. Маріуполь : МДУ, 2018. С. 179-188.

13.Війна зобов'язала поліцейських на Донбасі стати краще. Communiti policing : веб-сайт. URL: http://cop.org.ua/ua/ukrainskyidosvid/donetska-oblast/general-mikola-semenishin-vijna-zobov-yazalapolitsejskikh-na-donbasi-stavati-krashchimi (дата звернення 15.11.1019).

14.В Маріуполі запустили Єдиний аналітичний сервісний центр UASC. Everest.uа : веб-сайт. URL: https://www.everest.ua/v-mariupolizapustyly-yedynyy-analitychnyy-servisnyy-tsentr-uasc (дата звернення 15.11.1019).

15.Новий тлумачний словник української мови : у 4 т. Т. 1 / уклад.: В. Яременко, О. Сліпушко. Київ : Аконіт, 1998. 910 с.

16.Плішкін В. М. Теорія управління органами внутрішніх справ : підручник / за ред. Ю. Ф. Кравченка. Київ : Нац. акад. внутр. справ України, 1999. 702 с.

17.Програма громадської організації «Молодіжна ліга майбутніх поліцейських». Liga-police. ucoz.net : веб-сайт. URL: https://liga-police.ucoz.net/index/programa_gromadskoji_organizaciji_39_ 39_molodizhna_liga_majbutnikh_policejskikh_39_39/0-4 (дата звернення: 23.11.2019).

18. Проект «Ластівка»: 18 поліцейських Донеччини отримали сертифікати сурдоперекладачів. Mariupol-police.dn.ua : веб-сайт. URL: http://mariupol-police.dn.ua/news/view/3571 (дата звернення: 23.11.2019).

19.Поліція поширює проєкт протидії домашньому насильству «Поліна» на всю Україну - Клименко. Radiosvoboda.org : веб-сайт. URL: https://www.radiosvoboda.org/a/news-policija-poshyriye-proekt- 
protydii-domashniomu-nasylstvu-na-vsiu-ukrainu-klymenko/30204166. html (дата звернення: 23.11.2019).

20.Сусідська варта: безпека-добробут-порядок. На Галичині і в Донбасі. Prostir.uа : веб-сайт. URL: https://www.prostir.ua/?news= susidska-varta-bezpeka-dobrobut-poryadok-na-halychyni-i-v-donbasi (дата звернення: 23.11.2019).

21. До ініціативи «Тонка синя лінія» приєднався магазин побутової техніки. Mariupol-police.dn.ua : веб-сайт. URL: http://mariupol-police. dn.ua/news/view/4939 (дата звернення: 23.11.2019).

22.На Донеччині поліцейські впровадили проект «Шкільний офіцер поліції». Полічія Донеччини : веб-сайт. URL: http://police.dn.ua/ news/view/na-donechchini-politsejski-vprovadili-proekt-shkilnij-ofitserpolitsii (дата звернення: 23.11.2019).

\section{Information about the author:} Abroskin V. V., Doctor of Law, Rector of Odesa State University of Internal Affairs 1, Uspenska str., Odessa, 65000, Ukraine 